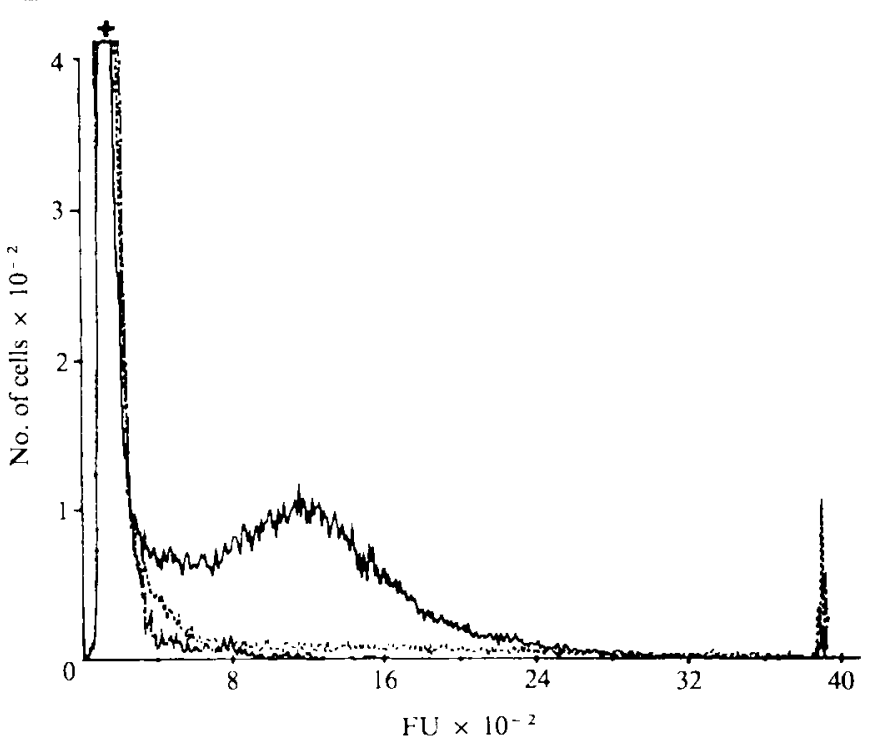

Fig. 2 Fetal thymocyte from B6-Ly-1 ${ }^{a}$ mice which express the Lyt 3.2 antigen were treated with anti-Lyt 3.2 serum $^{9}$ and FIGAMIg antibodies. At 17 days gestation (-), the IF is seen as a peak of positive cells whereas at day $16(-.-)$ the IF is less than $10 \%$ above the 16-day fetal thymocytes treated with FIGAMIg (_....) alone. The median value of the Lyt $3^{+}$cells was not noticeably changed in these experiments and varied only between 1,200 and 1,600 FU. The FlGAMIg control has $3.8 \%$ cells $>400$ FU and $1.6 \%$ of cells $>800 \mathrm{FU}$.

ways $^{17,18}$. An early cohort of thymic cells passes through the bursa of Fabricius, a B-cell differentiation site in birds, and takes up residence in the thymus. Cells, which populate thymus at a later time in development, apparently bypass the bursa. This parallels the two-stage distinct sequential appearance seen for the two Lyt phenotypes reported here. One might even consider that precursors of Lyt $1^{+} 23^{-}$cells pass some similar B-cell site at which a $\mathrm{T}$-helper function is in some way induced or programmed in the lineage. This is clearly hypothetical in the mouse, because no comparable unified B-cell generation site is known. However, there is evidence of separated functions of isolated subpopulations of Lyt differentiated peripheral T cells ${ }^{19}$.

Finally, a combination model is proposed in which Lyt $1^{+} 23$ cells give rise to two separate lineages only one of which 'seeks' a cortical site or pathway. This Lyt $123^{+}$lineage may require multiple divisions in the cortex for both functional and phenotypic differentiation and for repertoire development. The requirement for cell division has been documentated in other differentiation systems ${ }^{20}$. This model of separate lines with site-specific differentiation would be consistent with data and models of thymocyte differentiation presented by several investigators, including Weissman ${ }^{21}$, Shortman and Jackson ${ }^{15}$, Zinkernage $^{22}$ and Stutman ${ }^{23}$. Although Leckband and Boyse ${ }^{24}$ previously indicated a correlation with $\mathrm{TL}^{-}$phenotype of CRT, a presumably more mature medullary thymic subpopulation, recent observations of Kisielow et al. ${ }^{25}$ show $\mathrm{TL}^{+}$cells with differentiated Lyt phenotypes. Data obtained from analysis of thymic lymphomas ${ }^{26}$ led us to propose earlier that such immature thymocytes might exist which were $\mathrm{TL}^{+}$but differentiated for Lyt phenotype. Thus, we favour this latter combination model which presumes independent pre-committed lineages with site-specific differentiation and therefore presumes nothing about the maturity of cells found in either the cortical or medullary site in the thymus.

We thank the members of the Laboratory of Microbial Immunity who have encouraged and supported our work, especially Dr R. Asofsky and Ms B. J. Fowlkes for provision of fluorescent reagents used in these studies, and V. Shaw and $O$. Childers for preparation of the manuscript. We also thank Dr E. A. Boyse for provision of the original breeding stocks of the B6-Ly congeneic mice, Dr M. Potter for provision of experi- mental mice, through a NCI contract, and Drs J. Wunderlich, N. Jerne and $\mathrm{H}$. Holtzer for stimulating discussions during this work.

Received 18 July; accepted 4 November 1980

Boyse, F. A., Miyazawa, M., Aoki, T. \& Old, L. J. Proc. R. Soc. B170, 175-193 (1968). 2. Boyse, E. A., Itakura, K., Stockert, E., Iritani, C. A. \& Miura, M. Transplantation 11 , $351-353$ (1971).

3. Kisielow, P. et al Nature 253, 219-220 (1975)

4. Cantor, H. \& Boyse. E. A. J exp. Med. 141, 1376-1389 (1975)

Mathieson, B. J., Sharrow, S. O., Campbell, P. S. \& Asofsky, R. Nature 277, 478-480 (1979)

Cantor, H. \& Boyse, E. A. Immun. Rev. 33, 105-124 (1977)

Shen, $F$ W McDougal, S Bard, I \& Cort S P I exp. Med 151, 566-572 (1980)

Kamarck, M. E. \& Gottlieb, P. D. I. Immun. 119, 407-415 (1977)

Shen, F. W. Boyse, E. A. \& Cantor, H. Immunogenetics 2, $591-595$ (1975)

0. Betel, L., Mathicson, B. J., Sharrow, S. O. \& Asofsky, R. J. Immun. 124, 2209-2217 (1980)

1. Mandel, T. Z. Zellforsch. 106, 498-515 (1970).

2. Mandel, T. \& Russell, P. J. Immunology 21, 659-674 (1971)

3. Scollay, R., Kochen, J., Butcher, E. \& Weissman, I. Nature 276, 79-80 (1978)

4. Owen, J. J. T. \& Ritter, M. A. J. exp. Med. 129, 431-437 (1969).

Shortman, K \& Jackson, H. Cell Immun 12, 230-246 (1974).

5. Shortman, K. \& Jackson, H. Cell. Immun. 12,

7. LeDouarin, N. M. \& Jotereau, F. V. J. exp. Med. 142, 17-40 (1975)

8. Jotereau, F. V. \& Houssaint, E. in Developmental Immunobiology (eds Soloman, J. B. \& Horton, J. D.) 123-130 (Biomedical Press. Amsterdam, 1977).

19. Huber, B., Cantor, H., Shen, F.-W. \& Boyse, E. A. J. exp. Med. 144, 1128-1133 (1976) 20. Holtzer, H. in Stem Cells and Tissue Homeostasis (eds I ord, B. I., Potten, C. S. \& Cole, R. J. 1-27 (Cambridge University Press, 1978).

21. Weissman, I. L. J. exp. Med. 126, 291-304 (1967).

22. Zinkernagel, R. Immun. Rev. 42, 224-270(1978)

23. Stutman, O. Immun. Rev. 42, 138-184 (1978).

23. Stutman, O. Immun. Rev. 42, 138-184 (1978)

24. Leckband, F. \& Boyse, E. A. Science 172, 1258-1260 (1971).

25. Kisielow, P., Draher, P. \& Wysocka, M. Eur. J. Immun. 9, 1023-1025 (1979)

26. Mathieson, B. J., Campbell, P. S., Potter, M. \& Asofsky, R. J. exp. Med. 147, 1267-1279 (1978).

27. Loken, M. R. Herzenberg, L. A. Ann. N.Y. Acad. Sci. 254, 163-171 (1975).

28. Miller, M. H., Powell, J. I., Sharrow, S. O. \& Schultz, A. R. Rev. scient. Instrum. 49, $1137-1142$ (1978).

\section{Selective inhibition of T suppressor-cell function by a monosaccharide}

\section{Ulrich H. Koszinowski* \& Michael Kramer}

Institut für Immunologie und Genetik, DKFZ, 6900 Heidelberg, FRG

Interactions between regulatory $\mathbf{T}$ lymphocytes and other cells are assumed to occur at the level of the cell surface. T cells which suppress the generation of specifically effector cells have been described as having antigenic, idiotypic, allotypic and I-region specificity ${ }^{1-4}$. Other $T$ suppressor cells generated by in vitro cultivation with or without mitogenic stimulation ${ }^{5,6}$ have suppressive activity for $T$ and $B$ cells but no specificity can be assigned to them. These $T$ suppressor cells $\left(T_{s}\right)$ inhibit various lymphoid functions-this either reflects their polyclonal origin or indicates that the structures recognized by the $T_{8}$ receptors must be common for many cell types. Carbohydrates on cell membrane-inserted glycoproteins or glycolipids might function as specific ligands for recognition by cellular receptors or soluble factors. Almost all cell-surface proteins of mammalian cells are glycosylated. There is evidence for lectin-like carbohydrate binding proteins not only in plants ${ }^{7}$ but also in toxins ${ }^{8}$, viruses, prokaryotic cells ${ }^{10}$ and even mammalian cells, including $T$ cells $^{11}$. A functional role for these lectin-like proteins has been described for slime moulds and suggested for the selective association of embryonic cells ${ }^{12,13}$. We report here that addition of a monosaccharide can counteract the effect of $T$ suppressor cells during the generation of alloreactive cytotoxic $T$ cells (CTLs) in vitro.

* Present address: Federal Research Institute for Animal Virus Diseases, 7400 Tübingen. PO Box 1149 , FRG 


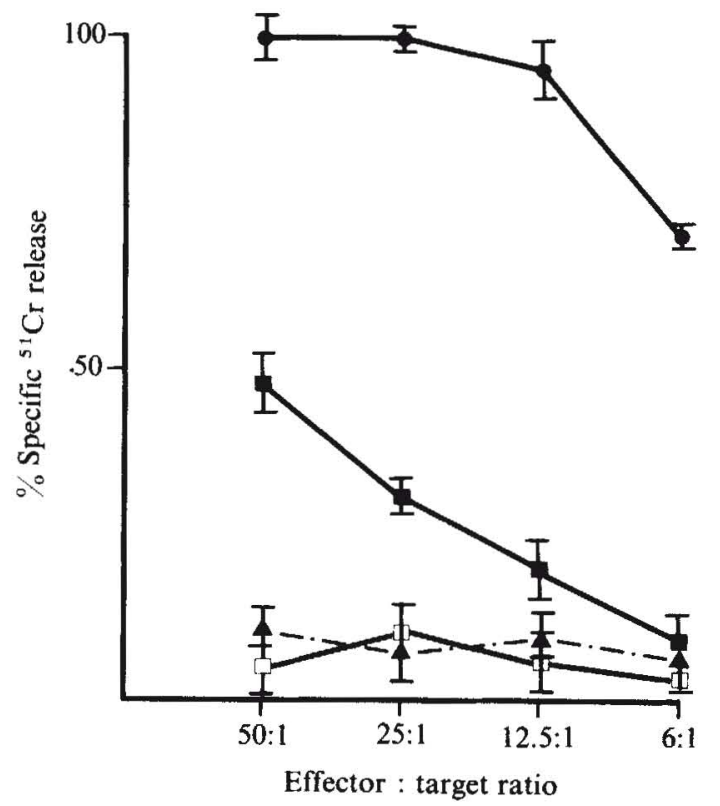

Fig. 1 Regulatory effects of MM on suppressor-cell function. Alloreactive CTLs were generated from C57BL/6J responder spleen cells by incubation with 2,000 rad-irradiated allogeneic DBA/2J spleen cells (6-8 week-old mice from the Institut für Versuchstierzucht, Hannover). Cells were cultivated in 24 flatbottom Linbro plates (Flow) at a responder/alloantigen ratio of $1: 1$ and a concentration of $2.5 \times 10^{6}$ responder cells per ml RPMI medium supplemented with $10 \%$ heat-inactivated fetal calf serum and antibiotics. Cells were collected 6 days later and tested for cytolytic activity in the ${ }^{51} \mathrm{Cr}$-release assay ${ }^{17}$ using $\mathrm{P}-815$ mastocytoma cells as targets. Suppressor cells $\left(T_{s}\right)$ from $C 57 \mathrm{BL} / 6 \mathrm{~J}$ mice were generated by precultivation in the absence of alloantigens using the method of Rollwagen and Stutman ${ }^{15}$ with the modification that erythrocyte lysis was omitted. When tested for cytolytic activity after 6 days, these cells were found to be negative $(\boldsymbol{\Delta})$. After addition of these precultivated cells to new cultures containing responder cells and alloantigens at the ratio of respon$\mathrm{der} / \mathrm{T}_{\mathrm{s}}$ varying from $1: 2$ to $1: 8$ (this experiment $1: 4$ ), production of alloreactive CTLs was abolished ( $\square$ ). Addition of $10 \mathrm{mg} \mathrm{ml}^{-1}$ MM (Roth; Sigma; Calbiochem; Hoechst) counteracted the suppressive effect (D). Experiments were carried out in triplicate. Bars indicate standard deviations.

Nonspecific suppressor-cell production in in vitro cultivated lymphocytes by the plant lectin concanavalin A (Con A) can be inhibited by the addition of methyl- $\alpha-\mathrm{D}$-mannopyranoside (MM) during the induction phase $\mathrm{e}^{14}$. We wondered whether similar phenomena could be demonstrated in a system without Con $\mathrm{A}$. $\mathrm{T}_{\mathrm{s}}$ were produced in vitro in cultures of spleen lymphocytes incubated in complete medium without antigenic stimulation for 6 days, as described elsewhere ${ }^{15}$. Suppressor cells produced in this way inhibit a variety of immune responses nonspecifically and without $\mathrm{H}-2$ restriction. When added in graded numbers to a primary mixed leukocyte culture (MLC) on day 0 , these cells were able to suppress or abolish the generation of alloreactive CTLs. This inhibitory activity was neither due to cell crowding effects (data not shown) nor to cytolytic activity in the suppressor cell populations ${ }^{16}$. Data from a representative experiment showed that generation of CTLs is abolished in the presence of suppressor cells (Fig. 1) and that these cells were not cytolytic after cultivation with antigen. Addition of $10 \mathrm{mg}$ per $\mathrm{ml}$ MM to the culture system counteracted the suppressive effect, resulting in the reconstitution of a cytolytic response.

Treatment of the transferred cells with anti-Thy-1.2 and complement abolished their suppressive effects, demonstrating that the MM-sensitive suppression is a $\mathrm{T}$ cell-dependent phenomenon (Fig. 2).
Table 1 Ability of methyl- $\alpha$-D-mannopyranoside (MM) to inhibit the function of suppressor cells

\begin{tabular}{|c|c|c|c|c|}
\hline $\begin{array}{c}\text { Molar } \\
\text { concentration } \\
\text { of sugar } \\
\text { during CTL } \\
\text { induction }\end{array}$ & $\begin{array}{l}\text { Ratio of } \\
\text { responder: } \\
\text { suppressor } \\
\text { cells }\end{array}$ & $\begin{array}{l}\text { Ratio of } \\
\text { killer: } \\
\text { target cells } \\
\text { required } \\
\text { for } 1 \mathrm{LU}\end{array}$ & $r^{2}$ & $\begin{array}{l}\% \mathrm{~T}_{\mathrm{s}} \\
\text { activity }\end{array}$ \\
\hline- & $1: 0$ & 10.0 & 0.97 & 0 \\
\hline- & $2: 1$ & 39.1 & 0.95 & 100 \\
\hline $10^{-2}$ & $2: 1$ & 15.8 & 0.99 & 20 \\
\hline $10^{-3}$ & $2: 1$ & 17.2 & 0.98 & 25 \\
\hline $10^{-4}$ & $2: 1$ & 18.6 & 1.00 & 30 \\
\hline $10^{-5}$ & $2: 1$ & 27.2 & 0.97 & 59 \\
\hline
\end{tabular}

Methyl- $\alpha$-D-mannopyranoside (Roth) was re-crystallized and added at different molar concentrations to the culture containing responder cells, allogeneic stimulator cells and suppressor cells. Effector cells produced in these conditions were tested for cytolytic activity at 4 effector: target cell ratios (third column). The killer: target cell ratio required for 1 lytic unit (LU), arbitrarily defined as the ratio resulting in $33 \%$ specific lysis in the $4-\mathrm{h}$ assay period, was calculated by logarithmic curve fitting ${ }^{17}, r$, Coefficient of determination. The cytolytic capacity of suppressed responder-cell cultures was taken as $100 \% \mathrm{~T}_{\mathrm{s}}$ activity.

Addition of the carbohydrate alone to the culture medium did not inhibit the generation of alloreactive CTLs. MM therefore does not interfere with antigen recognition, differentiation and expansion of alloantigen-specific T cells (Fig. $3 a$ ). Furthermore, no inhibition by MM was seen in the effector phase of cytolytic $\mathrm{T}$

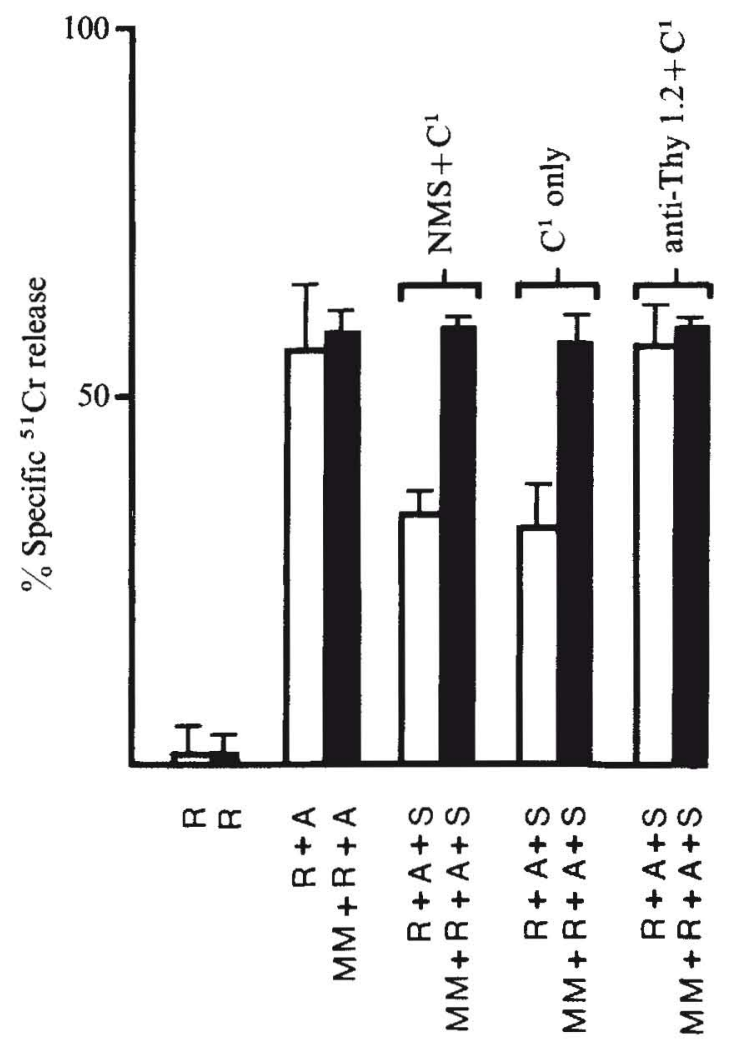

Fig. 2 Characterization of the MM-susceptible suppressor cells. Generation of alloreactive CTLs in presence or absence of MM and suppressor cells. After the 6-days induction phase, suppressor cells were incubated with either normal mouse serum (NMS) or antiThy- 1.2 serum ( $1: 20$ final dilution) for $30 \mathrm{~min}$ at $20^{\circ} \mathrm{C}$, centrifuged and resuspended in freshly thawed selected rabbit serum as a source of complement. Further incubation was at $37^{\circ} \mathrm{C}$ for $30 \mathrm{~min}$. $\mathrm{R}, \mathrm{C} 57 \mathrm{BL} / 6 \mathrm{~J}$ responder cells $\left(2.5 \times 10^{6} \mathrm{ml}^{-1}\right) ; \mathrm{A}, \mathrm{DBA} / 2 \mathrm{~J}$ allogeneic cells $\left(2.5 \times 10^{6} \mathrm{ml}^{-1}\right)$; $\mathrm{S}$, suppressor cells $\left(0.6 \times 10^{6} \mathrm{ml}^{-1}\right)$; MM, methyl- $\alpha$-D-mannopyranoside $\left(10 \mathrm{mg} \mathrm{ml}^{-1}\right)$. Effector: target cell ratio, $25: 1$; target, P-815 mastocytoma cells. 


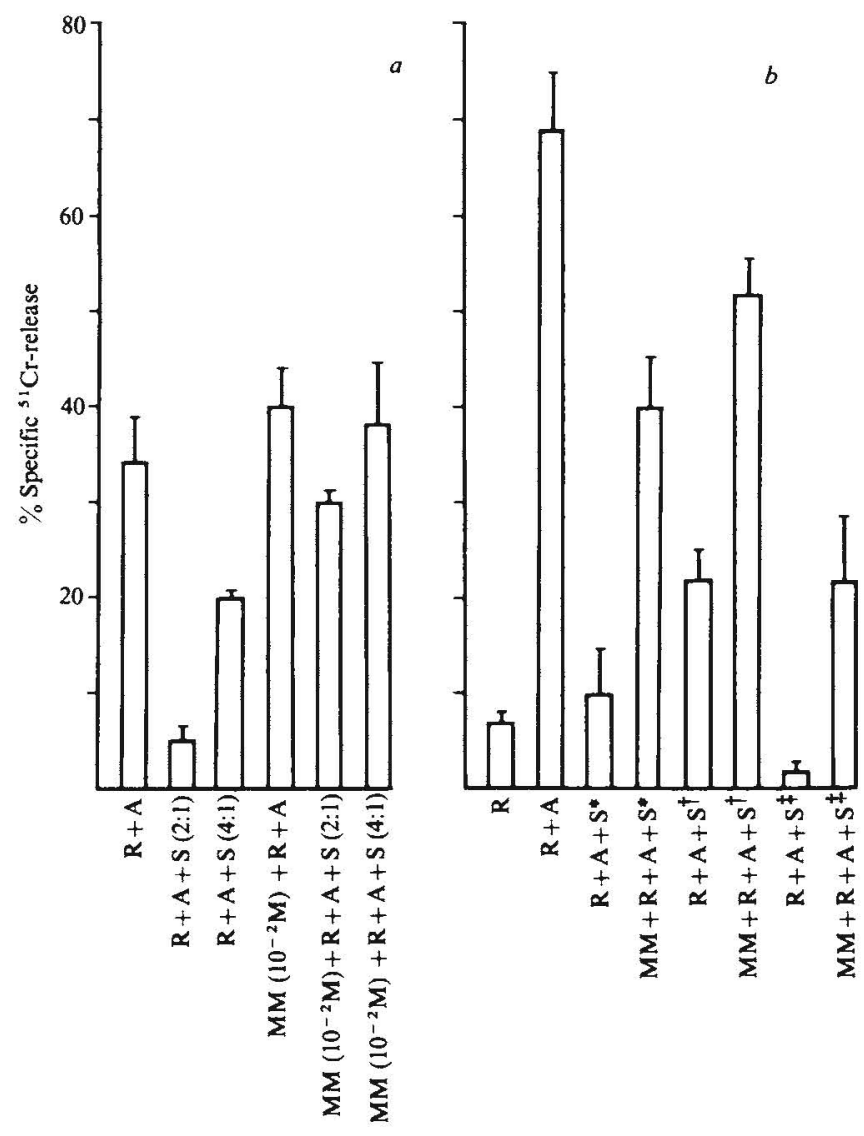

Fig. 3 Effect of MM on the generation of effector T cells. $a$, Effect on killer-cell generation. Responder cells $(R)$ in presence of allogeneic cells (A) (see Fig. 1 legend) generate CTLs (first column). This effector-cell generation is suppressed in presence of suppressor cells (S) added at different $\mathrm{R}: \mathrm{S}$ ratios at the start of culture. Addition of $\mathrm{MM}\left(10^{-2} \mathrm{M}\right)$ inhibits suppressor-cell function (columns 5,6 ) but not the generation of CTLs in the absence of suppressor-cells (column 4). $b$, Effect on suppressor-cell generation. * Suppressor cells (S) were generated as described in Fig. 1 legend and added to the culture to suppress CTL generation in presence or absence of $10 \mathrm{mg}$ per $\mathrm{ml} \mathrm{MM}$. † Suppressor cells were cultivated for the first $72 \mathrm{~h}$ of the 6-day induction period in the presence of $M M\left(10 \mathrm{mg} \mathrm{ml}^{-1}\right)$ and then tested for function in presence or absence of $\mathrm{MM}$. $\ddagger$ Suppressor-cell generation in presence of MM during the 6-day induction period. Effector/target cell ratio in both experiments, 50:1; responder/suppressor cell ratio in $b, 4: 1$.

cells because target cell lysis was the same in the presence or absence of MM (10 $\mathrm{mg} \mathrm{ml}^{-1}$ ) (data not shown). Similarly MM did not affect the induction phase of suppressor-cell generation (Fig. $3 b$ ). Spleen cells were cultivated in presence of MM either for the initial $72 \mathrm{~h}$ or the whole 6-day induction period before addition to the second culture. Both populations were found to have comparable suppressive activity when transferred to the MLC. This indicates that MM does not affect the generation of $\mathrm{T}_{\mathrm{s}}$ from their precursors. Furthermore, we found no evidence for reduced DNA synthesis $\left({ }^{3} \mathrm{H}\right.$-thymidine incorporation) or decreased viability of $T_{s}$ in culture in the presence of $M M$ (data not shown). However, the capacity of the suppressor cells to inhibit a primary CTL was inhibited when MM was added to the second culture (Fig. $3 b$ ). Due to the different susceptibility to carbohydrate in the culture medium, our results clearly define cytotoxicity and suppression in this system as two separable manifestations of effector $T$-cell functions, a fact which is only shown with difficulty during regulation of CTL generation by $\mathrm{T}_{\mathrm{s}}{ }^{18}$.

The effect of $\mathrm{MM}$ on $\mathrm{T}_{\mathrm{s}}$ effector function could be attributed to the carbohydrate and not to impurities of the reagent used because MM from different sources (data not shown) and also the re-crystallized sugar were equally effective (Table 1). Osmotic effects seem unlikely because several other monosaccharides were ineffective (Fig. 4). A toxic effect of $\mathrm{MM}$ on lymphocytes is also unlikely because concentrations even 100 fold higher than those active in our system were not toxic to leukocyte function ${ }^{19}$.

Our study demonstrates that cell interactions can be blocked by monosaccharides. Only the regulatory function of $T_{s}$ is counteracted-neither CTL effector function nor the generation of $T_{s}$ and CTLs is inhibited. At this stage it is impossible to determine how the $T_{\mathbf{s}}$ interact with their targets during CTL activation. Alternative mechanisms must be considered. The sugars may sterically interfere with structures involved in recognition of target cells by $T_{s}$. $M M$ could also have reversible selective inhibitory effects on $\mathrm{T}_{\mathrm{s}}$ metabolism, affecting function but not differentiation, perhaps by interfering with the glycosylation of recognition structures. We favour the hypothesis that recognition structures on $T_{s}$ or secreted $T_{s}$ products, by interaction with complementary structures on their target cells, mediate suppression and that the carbohydrate competitively blocks this interaction. Results obtained with stem cells ${ }^{20}$ and T cells $^{21}$ suggest that differentiation may be accompanied by a change in carbohydrate binding capacity of cell-surface components.

The fact that D-mannose is often found in mammalian glycoproteins either as core or end groups ${ }^{22}$ does not mean that the specificity resides only in this sugar. Other mono-, and in particular, oligosaccharides should be tested for specificity by determining the concentration required to inhibit the regulative $T$-cell interaction. The advantage of our system is that it studies functional interactions. However, one disadvantage is that the incorporation of sugar into cells may decrease their capacity to compete at the extracellular level and the concentration of

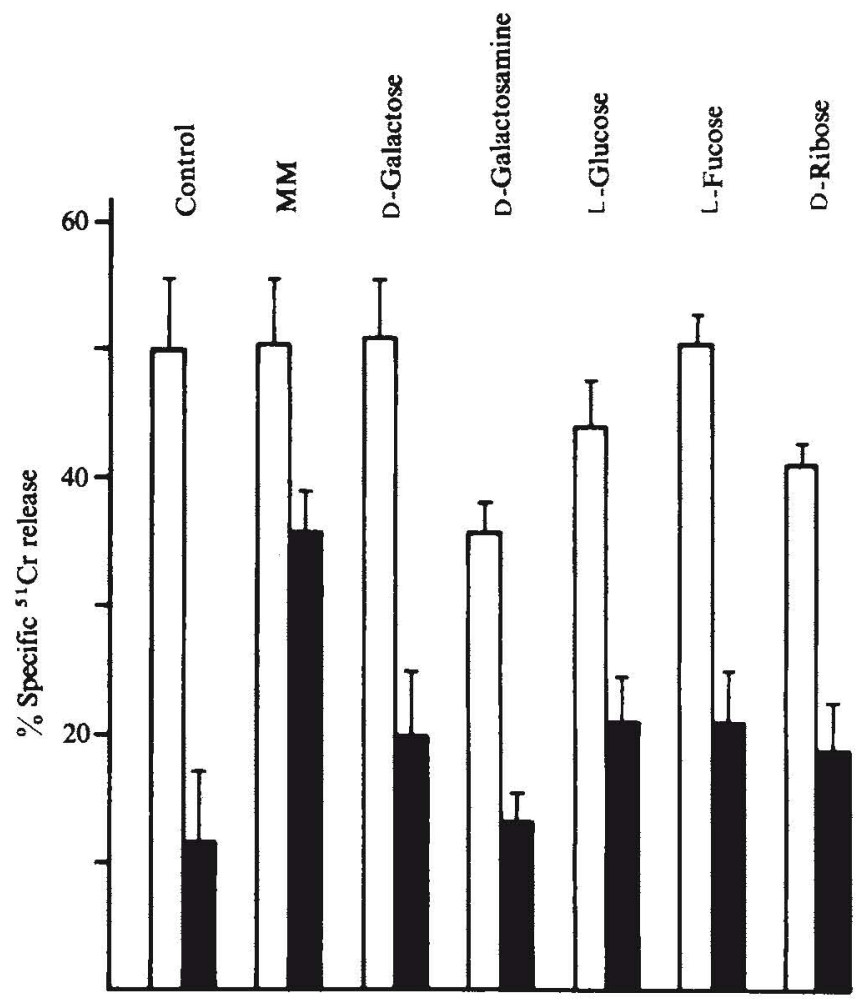

Fig. 4 Specificity of the carbohydrate effect on suppressor-cell functions. For suppressor and responder culture conditions, see Fig. 1 legend. The control shows the activity of responder cells incubated in absence (open columns) or presence (solid columns) of suppressor cells. In the other experimental groups different carbohydrates were added at $10^{-3} \mathrm{M}$ concentration during the induction phase to the suppressed and non-suppressed cell cultures. 
carbohydrates not toxic to effector-cell generation may not be sufficient to inhibit measurably suppression.

No definite function has been ascribed to oligosaccharides although their role in cell recognition has been suggested. Our observations on the counteraction of suppressor-cell activity suggest that carbohydrates play a part in T-cell regulation.

We thank Ms Ulrike Ette for technical help, Ms Ursula Rohmann for preparation of the manuscript, and our colleagues, in particular Dr M. Simon, for their criticisms. This work was partially supported by DFG grants Ko $571 / 5$ and $571 / 7$.

Received 7 July; accepted 3 November 1980.

1. Benacerraf, B., Kapp, J. A., Debré, P., Pierce, C. W. \& de la Croix, F. Transplantn Rev. 26, $21-38(1975)$

2. Eichmann, K. Eur. J. Immun. 5, 511-517 (1975).

3. Herzenberg, L. A., Okamura, K. \& Metzler, C. M. Transplantn Rev. 27, 57-83 (1975)

4. Tada, T., Taniguchi, M. \& Takemori, C. S. J. exp. Med. 144, 713-725 (1976).

5. Nadler, L. M. \& Hodes R. J. J. Immun. 118, 1886-1895 (1977).

6. Peavy, D. L. \& Pierce, C. W. J. exp. Med. 140, 356-369 (1974).

7. Lis, H. \& Sharon, N. A. Rev. Biochem. 42, 541-575 (1973).

8. Moss, J., Fishman, P. H., Manganiello, V. C., Vaughan, M. \& Brady, R. O. Proc nam. Acad. Sci. U.S.A. 73, 1034-1037 (1976)

9. Marchesi, V. T. \& Andrews, E. P. Science 174, 1247-1248 (1971)

10. Barondes, S. H. \& Rosen, S. D. in Neuronal Recognition (ed. Barondes, S.) 331-356 (Plenum, New York, 1976).

1. Boldt, D. H. \& Armstrong, J. P. J. clin. Invest. 57, 1068-1078 (1976)

12. Geltosky, J. E., Wesemann, J., Bahke, A. \& Lerner, R. A. Cell 18, 381-398 (1979).

13. Moscona, A. A. in Neuronal Recognition (ed. Barondes, S.) 205-226 (Plenum, New York, 1976).

14. Dutton, R. W. Transplantm. Rev. 26, 39-55 (1975)

15. Rollwagen, F. M. \& Stutman, O. J. exp. Med. 150, 1359-1366 (1979).

16. Ferguson, R. M. Anderson, S. M. \& Simmons, R. L Transplantation 26, 331-339 (1978).

17. Koszinowski, U. \& Simon, M. M. Eur. J. Immun. 9, 715-722 (1979).

18. Orosz, C. G. \& Bach, F. H. J. Immun. 124, 1419-1421 (1979).

18. Orosz, C. G. \& Bach, F. H. J. Immun. 124, 1419-1
19. Rocklin, R. E. J. Immun. 116, 816-820 (1976).

20. Grabel, L. B., Rosen, S. D. \& Martin, G. R. Cell 17, $477-484$ (1979)

21. Lehmann, V., Streck, H., Minner, I., Krammer, P. H. \& Ruschmann, E. Eur. J. Immun. (in the press).

22. McKenzie, I. F. C., Clarke, A. \& Parish, C. R. J. exp. Med. 145, 1039-1053 (1977)

\section{Is erythropoietin the only factor which regulates late erythroid differentiation?}

\section{Barbara Fagg*}

Biologie Cellulaire, Swiss Institute for Experimental Cancer Research, CH-1066 Epalinges s./Lausanne, Switzerland

Haematopoiesis is a useful model system for studying differentiation and the regulation of precursor cell populations intermediate between the multipotential stem cell and terminally differentiated end cells. For many years, erythropoietin (Epo) was recognized as the hormone which controls red cell production in vivo ${ }^{1}$. Although other substances are now known to be required during the initial stages of erythropoiesis ${ }^{2,3}$, late erythroid differentiation is regarded as strictly Epo-dependent ${ }^{4}$. This concept is supported by the recent demonstration that the addition of Epo alone to serum-free bone marrow cell cultures is sufficient to stimulate the CFU-E (colony-forming unit-erythroid-a late erythroid precursor cell approximating to a proerythroblast) to complete differentiation into mature erythrocytes. ${ }^{5}$ However, the data reported here indicate that mature erythroid colonies (indistinguishable from those formed by CFU-E + Epo) are formed when adult bone marrow cells are grown for $\mathbf{2} \mathbf{d}$ in methyl cellulose cultures containing spleen cell-conditioned medium (SCM) but no added Epo. SCM is a rich source of growth factors ${ }^{6,7}$ and initial observations ${ }^{8}$ suggested that its 'Epo-like' activity could be attributed to: (1) Epo, or (2) a factor which enhances the activity of small amounts of Epo in the culture medium, or (3) a factor(s) distinct from Epo which is also capable of stimulating late erythroid differentiation. The experiments reported here, which include a partial characterization of the 'Epo-like' activity, support the latter interpretation.

\footnotetext{
* Present address: Department of Microbiology, Medical Sciences I, University of California
} Irvine, California 92717

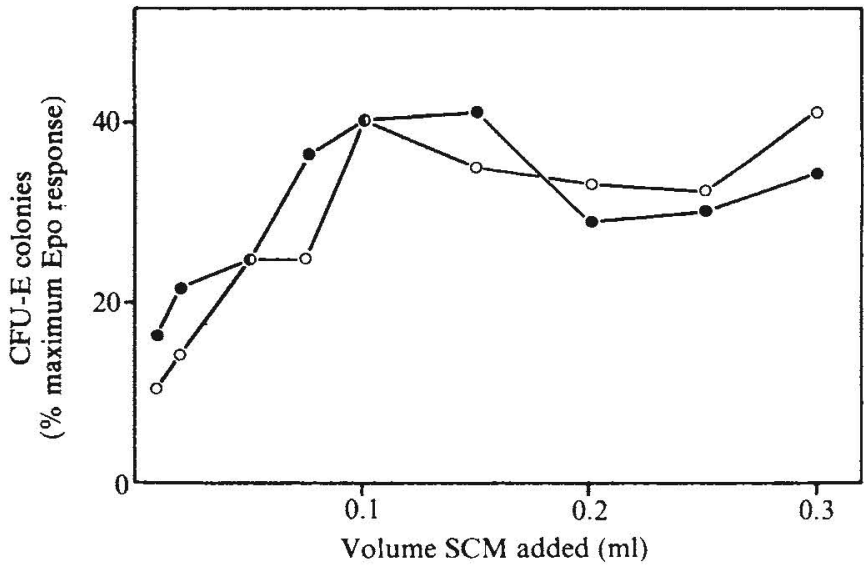

Fig. 1 Formation of erythroid colonies from adult mouse bone marrow cells grown for $2 \mathrm{~d}$ in vitro in the presence of different volumes of SCM. The number of CFU-E colonies is expressed as a percentage of the maximum response to Epo $(0.15$ units per $\mathrm{ml}$ culture; $307 \pm 31$ colonies per $10^{5}$ cells, mean \pm s.e.m. of 19 observations) in the same experiment. Epo was prepared from the urine of an aplastic anaemia patient according to Iscove $e t a l^{5,12}$. Either $20 \%(O)$ or $0 \%(O)$ fetal calf serum was added to the culture medium. Bone-marrow cell cultures contained $0.8 \%$ methyl cellulose, fetal calf serum $(0 \%$ or $20 \%), 32 \mu \mathrm{g} \mathrm{ml}^{-1}$ lecithin, $18 \mu \mathrm{g} \mathrm{ml} \mathrm{l}^{-1}$ cholesterol, $3.6 \times 10^{-6} \mathrm{M}$ human transferrin, $1 \%$ deionized BSA and $8 \times 10^{4}$ cells $\mathrm{ml}^{-1}$. They were evaluated as described by Iscove et al. ${ }^{12}$

SCM was collected from mouse spleen cells which had been stimulated with allogeneic irradiated spleen cells'. Adult $\mathrm{DBA} / 2 \mathrm{~J}$ mouse bone marrow cells grown for 7-10 $\mathrm{d}$ in vitro in the presence of SCM produced granulocyte/macrophage, megakaryocyte, erythroid (bursts) and mixed colonies. Similar results have been described previously using this type of SCM or that obtained from pokeweed mitogen(PMW)- or concanavalin A (Con A)-stimulated spleen cells ${ }^{10,11}$. The novel finding in the present study was that after 2 days in vitro, in the presence of SCM but no exogenous Epo, adult bone marrow cells produced colonies of 8-60 haemoglobinized (benzidine-positive) erythroid cells which were indistinguishable from those stimulated by Epo. Experiments designed to characterize this response in more detail showed that the number of erythroid colonies (cultured in the presence of $20 \%$ serum) increased in direct proportion to the amount of SCM added to the culture and reached a plateau value that was maintained at high SCM doses (Fig. 1). At a dose of SCM which maximally stimulated colony formation there was a linear relationship between the number of bone marrow cells plated $\left(0.25-4.0 \times 10^{5}\right.$ cells per plate $)$ and the number of erythroid colonies (correlation coefficient, $r=0.98$ ). This indicates that the response occurs at the level of the individual cell and that colony growth is not dependent on cooperation between cells in the culture.

Fetal liver cells are often used to assay growth factors because they are generally more responsive and contain a higher proportion of precursor cells than adult tissues. SCM had a similar 'Epo-like' effect on 12-day fetal liver cells in culture to that on adult bone marrow cells. SCM from Con A- and PWM-stimulated spleen cells (one sample of the latter was provided by $\mathrm{Dr} G$. R. Johnson, Melbourne, Australia) were also examined and found to contain a low level of 'Epo-like' activity when tested on adult bone marrow cells (data not shown).

All seven SCM preparations tested were active, although the level of 'Epo-like' activity varied between batches; the maximum response to SCM was between $41 \%$ and $80 \%$ of the maximum response to Epo, and required 33-150 $\mu$ l of SCM per $\mathrm{ml}$ culture medium. The activity did not seem to be derived from the serum used to prepare SCM, because batches of SCM containing 1,2 or $20 \%(\mathrm{v} / \mathrm{v})$ serum gave similar results and 